\title{
Title: Influence of urban green spaces on the conservation of bryophyte diversity: The special role of Japanese gardens
}

\begin{abstract}
Urban green spaces play a critical role in the maintenance of biodiversity in urban areas. However, bryophyte (moss) diversity in urban areas has received little attention. This study examined the role of urban green spaces in maintaining and enhancing bryophyte diversity. Four sites in Kanazawa City, northwestern Japan, were selected for the study based on differences in the utilization and maintenance practices: a Japanese garden, an urban park, a secondary forest, and a lawn. Bryophyte species richness and environmental characteristics were measured in sample plots $5 \mathrm{~m}$ in diameter (ca. $78.5 \mathrm{~m}^{2}$ ) along transects spanning the length and width of each green space. Bryophyte species richness was especially high in the garden relative to that observed in the other green spaces. Multiple linear regression models determined that bryophyte species richness was significantly correlated with increased areas of water and rocks, increased areas of restricted entry, and the presence of maintenance practices; grass cover, on the other hand, was negatively correlated with bryophyte species richness. The results suggest that high bryophyte species richness in the gardens is related to the diversity of environments created by the design and maintenance practices for keeping the garden looking beautiful. These design and maintenance practices can be applied to the creation of green space for the conservation of bryophyte diversity. Furthermore, the placement of logs and creation of patches with lower maintenance intensity can enhance the conservation of bryophyte diversity.
\end{abstract}

Keywords: biodiversity; urban area; design; maintenance; Japan 


\section{Short author biographies}

Yoshitaka Oishi is Assistant Professor of Landscape Ecology at Shinshu University, Japan. He completed his $\mathrm{PhD}$ on bryophyte diversity conservation in urban areas, at Kyoto University in 2007. His main research interest is on the conservation and ecology of bryophytes. His recent work also focuses on environmental monitoring using bryophytes as bio-indicators. 


\section{Research highlights}

The role of Japanese gardens in the conservation of bryophyte diversity was evaluated.

Bryophyte species richness was compared in several types of urban green spaces. The bryophyte species richness was especially high in a Japanese garden. This result can be explained by design and maintenance practices in Japanese gardens. They enhance habitat diversity and substrates suitable for bryophyte growth. 


\section{Acknowledgements}

The author would like to thank Anne McDonald, Director of the United Nations University Institute of Advanced Studies, Operating Unit Ishikawa/Kanazawa (UNU-IAS OUIK), and Dr. Koji Nakamura of Kanazawa University for their field survey support. This research was funded by UNU-IAS OUIK. 


\section{Introduction}

Biodiversity conservation in urban areas is an urgent issue due to the rapid decline of many animal and plant species in recent years (Mcdonald, Kareiva, \& Forman, 2008; McKinney, 2002; Pauchard, Aguayo, Peña, \& Urrutia, 2006). The conservation of animal and plant groups in urban areas has been the subject of numerous studies (Burton \& Samuelson, 2008; Clark, Reed, \& Chew, 2008; Croci, Butet, Georges, Aguejdad, \& Clergeau, 2008; Kühn \& Klotz, 2006; Savard, Clergeau, \& Mennechez, 2000); however, studies on bryophyte conservation have been insufficient, largely due to the combination of a shortage of bryologists generally and their overall lack of interest in researching urban vegetation/habitat types.

Research on bryophytes in urban areas suggests that edge effects caused by forest fragmentation strongly decrease bryophyte diversity (Baldwin \& Bradfield, 2007; Oishi, 2009; Pharo \& Zartman, 2007); habitat heterogeneity, on the other hand, increases bryophyte diversity (Cole, Newmaster, Bell, Pitt, \& Stinson, 2008; Gignac \& Dale, 2005; Pharo \& Zartman, 2007). Interestingly, high bryophyte diversities have been reported in Japanese gardens (Hasegawa, 2002), although this observation has not been statistically tested and confirmed. Considering that the identification of biodiversity hot spots is critical for ecologically oriented urban planning (Croci et al., 2008), patterns of bryophyte diversity in gardens require proper documentation and analysis. In this study, we evaluated the role of Japanese gardens in the conservation of bryophyte diversity, with a focus on the design and management of gardens to maximize and enhance the diversity of bryophytes. 


\section{Materials and Methods}

\subsection{Study sites}

This study was conducted in Kanazawa City $\left(36^{\circ} 33^{\prime} \mathrm{N}, 136^{\circ} 39^{\prime} \mathrm{E}\right)$, the capitol of Ishikawa prefecture, northwestern Japan (Fig. 1). The average temperature in Kanazawa ranges from $3.6^{\circ} \mathrm{C}$ in February to $26.6^{\circ} \mathrm{C}$ in August, and the annual precipitation is $2,470 \mathrm{~mm}$ (National Astronomy Observatory, 2009). The average precipitation during 1971-2000 was the highest in December $(2,869 \mathrm{~mm})$ and the lowest in April $(1,436 \mathrm{~mm})$ (National Astronomy Observatory, 2009).

Four different types of urban green spaces in the centre of Kanazawa, adjacent to one another, were selected as study sites (Fig. 2). These green spaces were as follows: a Japanese garden, an urban park, a secondary forest, and a lawn (Fig. 3). The garden (Kenrokuen Garden) is the largest site (ca. 11 ha), containing tea rooms, small hills (tsukiyama), several paths, and large ponds with streams. More than 10,000 trees were planted in this garden, and Pinus ssp. (e.g., $P$. densiflora) and P. spp. (e.g., P. mume) are especially abundant. This garden is maintained by hand weeding, pruning of overgrown trees, and clearing of fallen leaves to keep the garden looking beautiful. With the exception of the paths, public entry is prohibited to protect the ground cover. Although this garden was not designed for bryophyte growth, one bryophyte species (Polytrichum commune) is planted as a ground cover. Other bryophytes from the surroundings inhabited the garden naturally. The urban park (ca. 3 ha) has a large central open area, with trees such as Liquidambar styraciflua and Cedrus deodara planted on the perimeter. The maintenance of this park also involves hand weeding, pruning of overgrown trees, and removal of fallen leaves. However, the vegetation on the ground is reduced because of daily trampling by walkers. The secondary forest (ca. 5 ha) developed naturally after the 1950 s on a field used as army land. This forest has not been regularly managed, and the ground is covered with shrubs and fallen leaves, except on paths; the major tree species are Castanopsis sieboldii, Camellia japonica, Zelkova serrata, and Abies firma. The lawn (ca. 3 ha) is entirely covered with Zoysia matrellar and maintained by hand weeding. The garden, urban park, and lawn are often watered during the summer season. 


\subsection{Field survey}

In the 4 study sites, sample plots $5 \mathrm{~m}$ in diameter were located every $20 \mathrm{~m}$ along one transect spanning the length and along another transect spanning the width of each green space (Fig. 2), except in cases where the entire plot overlapped with buildings or ponds or where the plots were located on steep cliffs and thereby impossible to survey. The number of plots was 15 (15), 9 (2), 9 (2), and $9(0)$ in the garden, urban park, secondary forest, and the lawn, respectively (the number in parentheses indicates the number of plots with trees).

The study sites were surveyed between October and December 2009. I measured and recorded bryophyte species richness (the number of unique species) and the characteristics of each of the environments within the entire area of the sample plot.

The species richness of bryophytes was investigated on the ground and on tree trunks. Bryophytes on the ground (terrestrial bryophytes) included those on soil, humus, and rocks; bryophytes on tree trunks (corticolous bryophytes) were sampled from the lower $2.0 \mathrm{~m}$ of the trunks, including exposed roots, by detaching them with a small knife. In the water bodies, samples of all visible species were collected. The collected bryophytes were preserved by airdrying and returned to the laboratory for identification. Bryophyte nomenclature follows Iwatsuki (2001).

The vegetation cover was classified according to 4 categories: evergreen trees, deciduous trees, shrubs, and grassland. The evergreen and deciduous trees included both angiosperms (e.g., $C$. sieboldii and Prunus spp.) and gymnosperms (e.g., Pinus spp. and Ginkgo biloba). The vegetation cover was recorded using the Braun-Blanquet cover scale $(1=1-5 \%, 2=6-25 \%, 3=$ $26-50 \%, 4=51-75 \%, 5=76-95 \%)$ in each plot. The substrate type for the terrestrial bryophytes was based on the percentage of rocky areas and for the corticolous bryophytes was 
based on the total number, number of species, and the diameter at breast height (DBH) of evergreen vs. deciduous trees. The major rocks in these areas are sedimentary rocks. The environmental type included the percentage area of the water bodies and the topographic relief. The water bodies included ponds and streams. The maintenance type was measured by the presence/absence of maintenance practices (weeding, pruning, and clearing of fallen leaves). The size of the restricted areas was measured as a percentage of the total area in each sample plot. The percentage of rocky areas, water bodies, and restricted areas were recorded on a scale of 110 , in which one represented $10 \%$ or less within each plot. The topographic relief was measured using ranging poles.

\subsection{Analysis}

A multiple linear regression (MLR) model with an AIC-based model selection (Burnham and Anderson, 2002) was applied using R software for Windows 2.11.0 (R Development Core Team, 2010) to reveal relationships between bryophyte species richness and environmental variables. In this analysis, the types of urban green spaces (garden, park, secondary forest, and lawn) were included in the independent variables, while one planted species (P. commune) was excluded from the dependant variables. After the MLR models without interactions were constructed, final MLR models that incorporated the interactions between significant variables in the first MLR models were constructed to check the relationships between the selected variables. The interactions included those within environmental variables (e.g., vegetation, substrates, and types of urban green area) and those within maintenance types (presence/absence of maintenance and areas of restriction). Types of urban green areas and maintenance type were coded as 1/0 data. $p$ values represent $5 \%$.

Differences in bryophyte species richness and environments among the study sites were determined by ANOVA with a subsequent Tukey's multiple comparison test using the $\mathrm{R}$ software. The comparison for the terrestrial bryophytes and their growing environments was performed using all sampling plots, while that for the corticolous bryophytes was performed using only sampling plots with trees. 


\subsection{Species-area curve}

To quantify the turnover of bryophyte species composition among plots, an adjusted Whittaker's $\beta$-diversity (Whittaker, 1972) was calculated. The $\beta$-diversity (b) was defined as $\mathrm{b}=\mathrm{St} / \mathrm{Sm}$ where $\mathrm{St}=$ the total number of species found among samples at Nmin (minimum sample size among comparison groups) and $\mathrm{Sm}=$ the mean number of species found in each sample. In this study, the number of species at $(\mathrm{St})$ at Nmin was determined using the species-area curve function in PC-ORD for Windows, version 5.10 (McCune \& Mefford, 2006). This program calculates the species-area curves with a random sequence of subsamples (up to 500 times). The $\beta$-diversity was calculated using Nmin $=9$ for terrestrial bryophytes and $\mathrm{Nmin}=2$ for corticolous bryophytes. 


\section{Results}

\subsection{Environmental conditions}

Table 1 shows multiple comparisons between environmental conditions in the study plots. The garden was characterized by a larger proportion of evergreen trees, larger area of water, larger restricted area, and more maintenance practices. Higher values for rocky area and topographic relief were also recorded in the garden, although these differences were not significant. With regard to maintenance practices, green spaces excluding those for secondary forests were managed regularly. No significant differences were observed in the substrate type of corticolous bryophytes among the study plots.

\subsection{Species richness}

Across the study sites, 91 species (62 moss, 28 liverwort, and 1 hornwort species) were found. The total number of terrestrial bryophyte species in the garden, urban park, secondary forest, and lawn was $72,18,1$, and 1, respectively. Moreover, the total number of corticolous bryophytes species in the garden, urban park, and secondary forest was 36,4 , and 4 , respectively. The mean species richness of the terrestrial bryophytes per plot was the highest in the garden (mean $\pm \mathrm{SD}=$ $19.7 \pm 6.7)$, followed by the urban park $(3.6 \pm 2.6)$, the secondary forest $(0.2 \pm 0.4)$, and the lawn $(0.1 \pm 0.3)$. A similar trend was also observed for the corticolous bryophytes (see Table 1).

\subsection{MLR model results}

The final MLR models, constructed using environmental variables and maintenance types, are presented in Table 2. The species richness of the terrestrial bryophytes showed a significant positive relationship with rocky areas, areas of water, site management, and site restriction, and a significant negative relationship with grass cover. The species richness of the corticolous bryophytes showed only a significant positive relationship with a type of urban green space (garden). The MLR models for species richness of terrestrial and corticolous bryophytes explained $93.0 \%$ and $43.5 \%$ of the variance, respectively ( $p<0.01$ for both models). 


\section{$3.4 \beta$-diversity}

The $\beta$-diversity for terrestrial bryophytes was the highest in the garden $(\beta=12.7)$ when compared to that of the other study sites ( $\beta=9.0$ in the other 3 sites). The $\beta$ diversity for the corticolous bryophytes showed similar results; the highest value was in the garden $(\beta=4.5)$, followed by the secondary forest $(\beta=2.4)$, and the park $(\beta=2.0)$. The species-area curves are shown in Fig. 4. 


\section{Discussion}

\subsection{Habitat diversity}

The positive relationship between species richness and the area of the rocks and water can be explained by the ways in which these factors enhance the types of habitat for bryophytes. Moisture availability is one of the important factors contributing to bryophyte reproduction and growth since bryophytes are poikilohydric plants; that is, they are unable to actively control their water content due to the lack of waterproof cuticles and vascular systems (Bates, 1998). Because they rely on passive mechanisms to control water status, bryophytes tend to inhabit humid habitats (Oishi, 2009). This poikilohydric property, on the other hand, enables bryophytes to grow on rocks, an environment inhospitable to other plants, because they can directly absorb water from ambient air or rain through their tissue surfaces (Bates, 1998). Hylander and Dynesius (2006) suggested that boulders are able to raise bryophyte species richness in a boreal streamside forest because they increase both microtopographical and microclimatic heterogeneity near the stream. Considering that water and rocky areas are scarce in the study sites, with the exception of the garden, the increased species richness in the garden may be due to the water and rocky areas leading to an increase in the habitat diversity. Indeed, species frequently found on rocks (e.g., Schistidium strictum, Philonotis falcate, Thamnobryum subseriatum, and so on) and in or nearby water bodies (e.g., Hypnum lindbergii Pellia endiviifolia, Conocephalum conicum, and so on) were found in the sites.

\subsection{Maintenance practices and grass coverage}

Species richness of terrestrial bryophytes is positively correlated with maintenance practices and negatively correlated with grass coverage. These relationships can be explained by the vulnerability of bryophytes to coverage by other vegetation. Because of their small size, bryophytes are easily shaded by other vegetation or fallen leaves, and this shading has a strong negative impact on bryophytes by reducing their photosynthetic activity (Bergamini, Pauli, Peintinger, \& Schmid, 2001; During, 1979). Maintenance practices such as weeding are effective in preventing the suppression of bryophytes by taller and more dense vascular plant (herbaceous) vegetation. 
In addition to maintenance practices, the size of restricted areas also has a positive influence on the species richness of terrestrial bryophytes. Previous studies have suggested that bryophytes are vulnerable to trampling (Hamberg, Lehvävirta, Malmivaara-Lämsä, Rita, \& Kotze, 2008). However, despite possessing the largest proportion of restricted areas, the secondary forest had low species richness. This can be explained by the fact that the unmanaged forest floor is covered by fallen leaves and is shaded by overgrown vegetation not suitable for bryophyte growth. These results indicate that maintenance practices and the size of the restricted areas seem to interact; however, this interaction was not selected in the final MLR models. The high correlation of the interaction term (restricted area $\times$ maintenance practice) with the size of the restricted areas $(r=0.57)$ can cause a drop-off of this interaction during the model selection.

In terms of the corticolous bryophytes, the only variable selected by the MLR model was the garden. This result can be explained by the maintenance practices, biased sample sizes, and host tree species. The practices (e.g., pruning of overgrown trees and the removal of newly invading trees) used to maintain the garden design enhances bryophyte diversity, especially photophilous species, by increasing the amount of sunlight available for photosynthesis. However, the garden, instead of the maintenance practices, was selected as the significant variable in the MLR model. This selection can be related to the small contribution of the urban park to explain variance in the species richness due to the small sample size ( 2 plots) compared to those of the garden (15 plots). Additionally, considering that the host tree species is one of the major factors determining the distribution of corticolous bryophytes (Király \& Ódor, 2010), the differences in host tree species between the garden and urban park can also affect the variable selection, which is not well represented in the explanatory variables.

\subsection{Environmental conditions and maintenance practices in Japanese gardens}


The results of multiple comparison tests indicate that the garden has larger areas of water, rocks, and restricted areas, and more active maintenance practices. All of these environmental variables are positively correlated with bryophyte species richness, as discussed above.

The larger areas of water and rocks appear to be a special feature of Japanese gardens, which try to imitate some features often found in natural landscapes (mountains, ponds, waterfalls, beaches, islands, and so on) but at a smaller scale in miniature using vegetation, stones, and topographic relief in order to symbolize the world view and special significance of nature developed in Zen Buddhism (Shinji, 1989). For example, a number of rock formations and islands in gardens are thought to represent the Crane (e.g., Grus japonensis), which symbolizes longevity in Chinese and Japanese traditions. The creation of these elements appears related to the enhancement of bryophyte habitat diversity and species richness in the garden. Furthermore, the arrangement of rocks around ponds and streams in the garden creates wet rocks, increasing the diversity of the rock environments. This habit diversity created by the garden design seems to increase both the $\alpha$ and $\beta$ diversity since the types of environments and substrates were not homogeneous both within and between plots.

Previous studies have reported that decaying logs were important substrates for maintaining the presence of rare species and for species diversification (Cole, et al., 2008; Hylander \& Dynesius, 2006); however, these substrates were not found in the garden because trees that have die backed or been cut are usually removed as soon as possible. Therefore, the placement of logs in the garden may be a means to effectively increase bryophyte diversity.

Special attention to the management practices in the gardens (e.g., weeding, pruning, and clearing fallen leaves, creation of restricted areas) also contributes to the high species richness of both terrestrial and corticolous bryophytes in this type of environment. 
Thus, maintenance practices can raise species richness; however, they may have negative effects on some sciophylous species. To conserve these species, several patches with lower maintenance intensity may be needed. 


\section{Conclusions}

The design (e.g., a larger area of rocks and water bodies) and maintenance practices (e.g., hand weeding, pruning of overgrown trees, clearing of fallen leaves, and the creation of restricted areas) in the Japanese garden can be applied to the creation of green space for the conservation of bryophyte diversity. Additionally, the placement of logs and the creation of patches with lower maintenance intensity can enhance the conservation of bryophyte diversity.

In urban areas, Japanese gardens play an important role in the conservation of bryophyte diversity. Considering the importance of remnant natural habitats in supporting biodiversity conservation in urban areas (Croci et al., 2008), the integration of the gardens into urban landscapes is an important component of conservation plans for bryophyte diversity. 


\section{References}

Baldwin, L.K. \& Bradfield, G.E. (2007). Bryophyte responses to fragmentation in temperate coastal rainforests: a functional group approach. Biological Conservation, 136, 408-422.

Bates, J.W. (1998). Is “life-form” a useful concept in bryophyte ecology? Oikos, 82, 223-237.

Bergamini, A., Pauli, D., Peintinger, M. \& Schmid, B. (2001). Relationships between productivity, number of shoots and number of species in bryophytes and vascular plants. Journal of Ecology, 89, 920-929.

Burnham, K.P. \& Anderson, D. (2002). Model selection and multimodel inference: a practical information-theoretic approach. 2nd edition. New York: Springer Verlag.

Burton, M.L. \& Samuelson, L.J. (2008). Influence of urbanization on riparian forest diversity and structure in the Georgia Piedmont, US. Plant Ecology, 195, 99-115.

Clark, P.J., Reed, J.M. \& Chew., F.S. (2007). Effects of urbanization on butterfly species richness, guild structure, and rarity. Urban Ecosystems, 10, 321-337.

Cole, H.A., Newmaster, S.G., Bell, F.W., Pitt, D. \& Stinson, A. (2008). Influence of microhabitat on bryophyte diversity in Ontario mixedwood boreal forest. Canadian Journal of Forest Research, 38, 1867-1876.

Croci, S., Butet, A., Georges, A., Aguejdad, R. \& Clergeau, P. (2008). Small urban woodlands as biodiversity conservation hot-spot: a multi-taxon approach. Landscape Ecology, 23, 1171-1186.

During, H.J. (1979). Life strategies of bryophytes: a preliminary review. Lindbergia, 5, 2-18.

Gignac, L.D. \& Dale, M.R.T. (2005). Effects of fragment size and habitat heterogeneity on cryptogam diversity in the low-boreal forest of western Canada. The Bryologist, 108, 50-66.

Hamberg, L., Lehvävirta, S., Malmivaara-Lämsä, M., Rita, H. \& Kotze, D.J. (2008). The effects of habitat edges and trampling on understorey vegetation in urban forests in Helsinki, Finland. Applied Vegetation Science, 11, 83-98. 
Hasegawa, J. (2002). Bryophytes flora in Saihoji temple (Koke-dera). In: Planning and environment department of Kyoto Prefecture (Eds.), The red data book of Kyoto Prefecture, vol 2. (pp. 292-297). Kyoto: Kyoto Prefectural Government (in Japanese).

Hylander, K. \& Dynesius, M. (2006). Causes of the large variation in bryophyte species richness and composition among boreal streamside forests. Journal of Vegetation Science, 17, 333-346.

Iwatsuki, Z. (2001). Mosses and Liverworts of Japan. Tokyo: Heibonsha (in Japanese).

Király, I. \& Ódor, P. (2010). The effect of stand structure and tree species composition on epiphytic bryophytes in mixed deciduous-coniferous forests of Western Hungary. Biological Conservation, 143, 2063-2069.

Kühn, I. \& Klotz, S. (2006). Urbanization and homogenization - Comparing the floras of urban and rural areas in Germany. Biological Conservation, 127, 292-300.

Mcdonald, R.I., Kareiva, P. \& Forman, R.T.T. (2008). The implications of current and future urbanization for global protected areas and biodiversity conservation. Biological Conservation, $141,1695-1703$.

McKinney, M.L. (2002). Urbanization, biodiversity, and conservation. BioScience, 52, 883-890.

McCune, B. \& Mefford, M.J. (2006). PC-ORD. Multivariate analysis of ecological data. Version 5.10. Oregon: MjM Software.

National Astronomical Observatory. (2009). Rika Nenpyo (Chronological Scientific Tables 2007). Tokyo: Maruzen (in Japanese).

Oishi, Y. (2009). A survey method for evaluating drought-sensitive bryophytes in fragmented forests: a bryophyte life-form based approach. Biological Conservation, 142, 2854-2861.

Pauchard, A., Aguayo, M., Peña, E. \& Urrutia, R. (2006). Multiple effects of urbanization on the biodiversity of developing countries: the case of a fast- growing metropolitan area (Concepción, Chile). Biological Conservation, 127, 272-281. 
Pharo, E.J. \& Zartman, C.E. (2007). Bryophytes in a changing landscape: the hierarchical effects of habitat fragmentation on ecological and evolutionary processes. Biological Conservation, $135,315-325$.

R Development Core Team. (2010). R: A Language and Environment for Statistical Computing. Vienna: R Foundation for Statistical Computing,

Savard, J.-P.L., Clergeau, P. \& Mennechez, G. (2000). Biodiversity concepts and urban ecosystems. Landscape and Urban Planning, 48, 131-142.

Shinji, I. (1989). Studies on the characteristics of Japanese gardens. Journal of the Japanese Institute of Landscape Architecture, 53, 23-31 (in Japanese).

Whittaker, R.H. (1972). Evolution and measurement of species diversity. Taxon, 21, 213-251. 


\section{Table captions}

Table 1. Comparison of the environments in sample plots among the study sites. Lowercase letters $(\mathrm{a}, \mathrm{b}$, and $\mathrm{c})$ indicate significant differences $(p<0.05)$, as determined by Tukey's multiple comparison test. Eve $=$ evergreen tree, Dec $=$ deciduous trees, Num. $=$ total number, Sp. $=$ species richness, $\mathrm{DBH}=$ diameter at breast height.

Table 2. Results of generalized liner models comparing terrestrial and corticolous bryophytes in terms of the characteristics of their respective environments. Eve = evergreen tree. 
Tables

Table 1

\begin{tabular}{|c|c|c|c|c|c|c|}
\hline & $\begin{array}{c}\text { Japanese } \\
\text { garden }\end{array}$ & $\begin{array}{c}\text { Urban } \\
\text { park }\end{array}$ & $\begin{array}{c}\text { Secondary } \\
\text { forest }\end{array}$ & Lawn & alue & $p$ \\
\hline \multicolumn{7}{|l|}{ Species richness } \\
\hline Terrestrial bryophytes & $\begin{array}{c}20.6 \pm 6.8 \\
\mathrm{a}\end{array}$ & $\begin{array}{c}3.6 \pm 2.6 \\
\mathrm{ab}\end{array}$ & $\begin{array}{c}0.2 \pm 0.4 \\
\mathrm{~b}\end{array}$ & $0.1 \pm 0.3$ & 66.4 & $<0.01$ \\
\hline Corticolous bryophytes & $\begin{array}{c}6.4 \pm 4.6 \\
\mathrm{a}\end{array}$ & $\begin{array}{c}1.5 \pm 0.7 \\
\mathrm{ab}\end{array}$ & $\begin{array}{c}0.6 \pm 1.3 \\
b\end{array}$ & - & 7.7 & $<0.01$ \\
\hline Vegetation cover $(\%)$ & & & & & & \\
\hline Eve & $\begin{array}{c}45.7 \pm 26.8 \\
\mathrm{a}\end{array}$ & $\begin{array}{c}9.9 \pm 23.0 \\
b c\end{array}$ & $\begin{array}{c}54.2 \pm 37.7 \\
\mathrm{ab}\end{array}$ & $\begin{array}{c}0.0 \pm 0.0 \\
\mathrm{c}\end{array}$ & 10.2 & $<0.01$ \\
\hline Dec & $\begin{array}{c}10.3 \pm 15.9 \\
\text { bc }\end{array}$ & $\begin{array}{c}6.2 \pm 18.7 \\
b c\end{array}$ & $\begin{array}{c}29.7 \pm 28.8 \\
\mathrm{ab}\end{array}$ & $\begin{array}{c}0.0 \pm 0.0 \\
\mathrm{c}\end{array}$ & 4.3 & $<0.01$ \\
\hline Shrubs & $\begin{array}{c}3.0 \pm 3.6 \\
\text { bc }\end{array}$ & $\begin{array}{c}0.6 \pm 1.7 \\
\text { bc }\end{array}$ & $\begin{array}{c}52.7 \pm 34.6 \\
a\end{array}$ & $\begin{array}{c}0.0 \pm 0.0 \\
b\end{array}$ & 24.2 & $<0.01$ \\
\hline Grassland & $\begin{array}{c}10.0 \pm 19.4 \\
b\end{array}$ & $\begin{array}{c}29.5 \pm 27.0 \\
b\end{array}$ & $\begin{array}{c}13.3 \pm 14.8 \\
b\end{array}$ & $\begin{array}{c}100.0 \pm 0.0 \\
\mathrm{a}\end{array}$ & 51.0 & $<0.01$ \\
\hline Substrate type & & & & & & \\
\hline Rocky areas (\%) & $\begin{array}{c}2.7 \pm 5.9 \\
a\end{array}$ & $\begin{array}{c}0.0 \pm 0.0 \\
\mathrm{a}\end{array}$ & $\begin{array}{c}0.0 \pm 0.0 \\
a\end{array}$ & $\begin{array}{c}0.0 \pm 0.0 \\
\mathrm{a}\end{array}$ & 1.7 & 0.17 \\
\hline Num. of Eve & $\begin{array}{c}1.8 \pm 2.2 \\
\mathrm{a}\end{array}$ & $\begin{array}{c}2.0 \pm 2.8 \\
\mathrm{a}\end{array}$ & $\begin{array}{c}2.1 \pm 2.5 \\
\mathrm{a}\end{array}$ & $\begin{array}{l}- \\
-\end{array}$ & 0.04 & 0.95 \\
\hline Num. of Dec & $\begin{array}{c}0.6 \pm 0.8 \\
\mathrm{a}\end{array}$ & $\begin{array}{c}2.0 \pm 2.8 \\
\mathrm{a}\end{array}$ & $\begin{array}{c}1.9 \pm 1.8 \\
\mathrm{a}\end{array}$ & $\begin{array}{l}- \\
-\end{array}$ & 2.5 & 0.1 \\
\hline
\end{tabular}


(Continued)

Num. of Eve species

$1.3 \pm 1.2 \quad 0.5 \pm 0.7 \quad 1.3 \pm 1.0$

$0.5 \quad 0.6$

a

a

a

Num. of Dec species

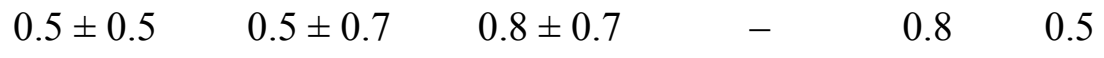

a

a

a

DBH of Eve $\left(\mathrm{m}^{2}\right)$

$50.1 \pm 53.3 \quad 99.5 \pm 140.6 \quad 90.0 \pm 77.4$

$1.2 \quad 0.3$

a

a

a

DBH of Dec $\left(\mathrm{m}^{2}\right)$

$22.3 \pm 31.9 \quad 90.1 \pm 127.4 \quad 25.6 \pm 29.9$

$2.5 \quad 0.1$

a

$\mathrm{a}$

a

\section{Environment types}

Topographic relief (m)

$$
0.7 \pm 1.1
$$$$
0.0 \pm 0.0
$$

$0.4 \pm 1.0$

$0.0 \pm 0.0$

2

0.13

a

a

a

a

Areas of water (\%)

$$
12.0 \pm 15.1
$$

$0.0 \pm 0.0$

$0.0 \pm 0.0$

$0.0 \pm 0.0$

$5.5<0.01$

a

b

b

b

\section{Maintenance types}

Restricted areas (\%)

$84.3 \pm 18.2$

$0.0 \pm 0.0$

$100.0 \pm 0.0$

$0.0 \pm 0.0$

$232<0.01$

b

c

$\mathrm{a}$

c

Maintenance practices

Present

Present

Absent

Present 
Table 2

\begin{tabular}{|c|c|c|c|c|c|c|}
\hline & \multicolumn{3}{|c|}{ Terrestrial bryophytes } & \multicolumn{3}{|c|}{ Corticolous bryophytes } \\
\hline & efficients & $t$-value & $p$ & coefficients & $t$-value & $p$ \\
\hline Intercept & -13.12 & -6.59 & $<0.01$ & -1.08 & -0.77 & 0.44 \\
\hline \multicolumn{7}{|l|}{ Vegetation cover } \\
\hline Grasses & -0.60 & -4.06 & $<0.01$ & - & - & - \\
\hline \multicolumn{7}{|l|}{ Substrate types } \\
\hline Rocky areas & 3.48 & 2.52 & 0.02 & - & - & - \\
\hline DBH of Eve & - & - & - & 0.02 & 1.90 & 0.07 \\
\hline \multicolumn{7}{|l|}{ Environment type } \\
\hline Areas of water & 0.12 & 2.23 & 0.03 & - & - & - \\
\hline \multicolumn{7}{|l|}{ Management types } \\
\hline Restricted areas & 1.42 & 8.66 & 0.03 & - & - & - \\
\hline Maintenance practices & is 18.85 & 12.32 & $<0.01$ & 5.27 & 3.35 & $<0.01$ \\
\hline \multicolumn{7}{|l|}{ Green-space type } \\
\hline Garden & - & - & - & 6.49 & 4.58 & $<0.01$ \\
\hline Variance explained & & $1.8 \%$ & & & $43.5 \%$ & \\
\hline
\end{tabular}




\section{Figure captions}

Fig. 1. Location of Kanazawa city in Japan.

Fig. 2. Sample plots in the study sites.

Fig. 3. Views of the study sites.

Fig. 4. Species-area curves for 4 green spaces (garden, urban park, secondary forest, and lawn). The area of each plot is $5 \mathrm{~m}$ in diameter $\left(\right.$ ca. $\left.78.5 \mathrm{~m}^{2}\right)$. 


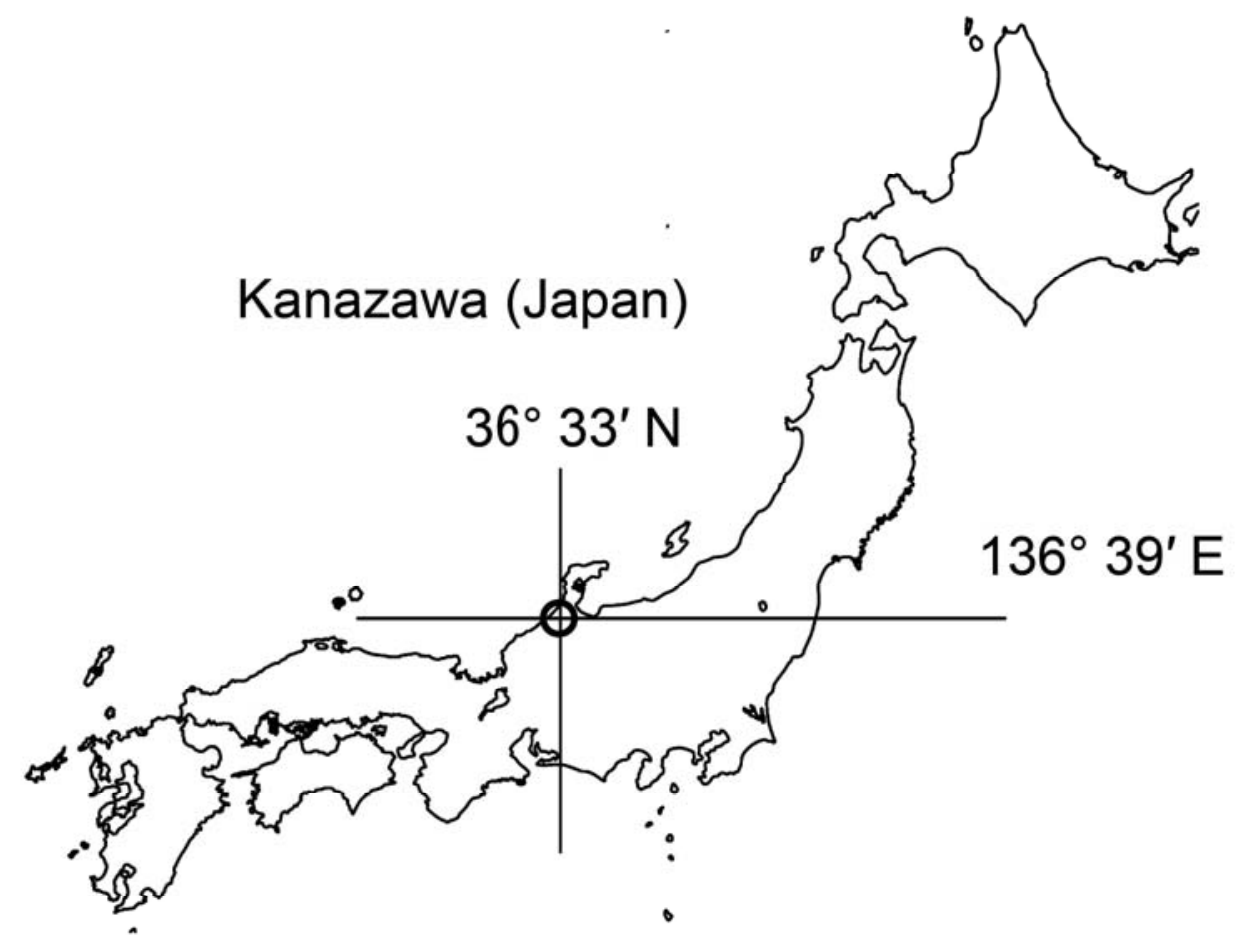

Fig. 1 


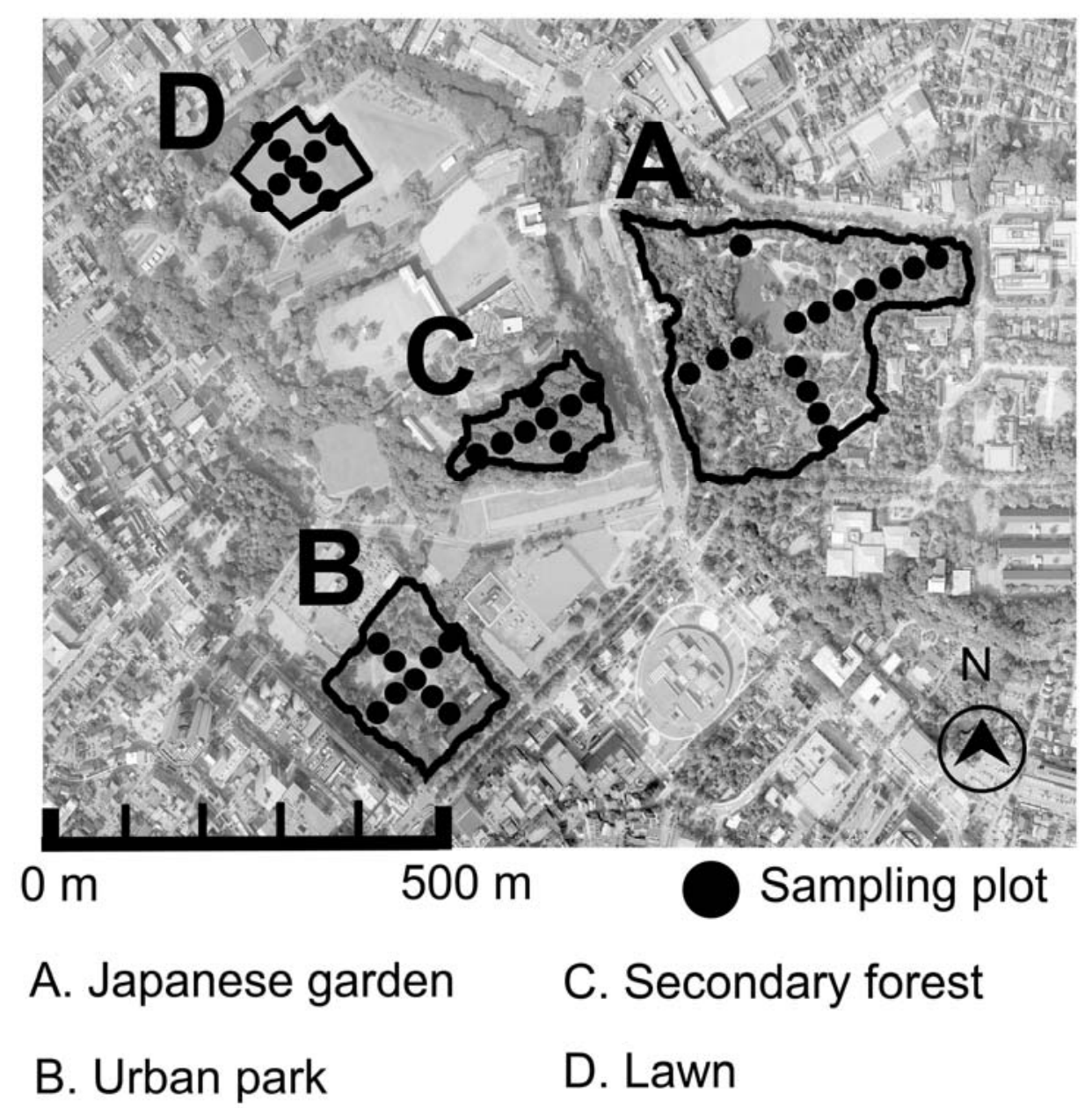

Fig. 2 

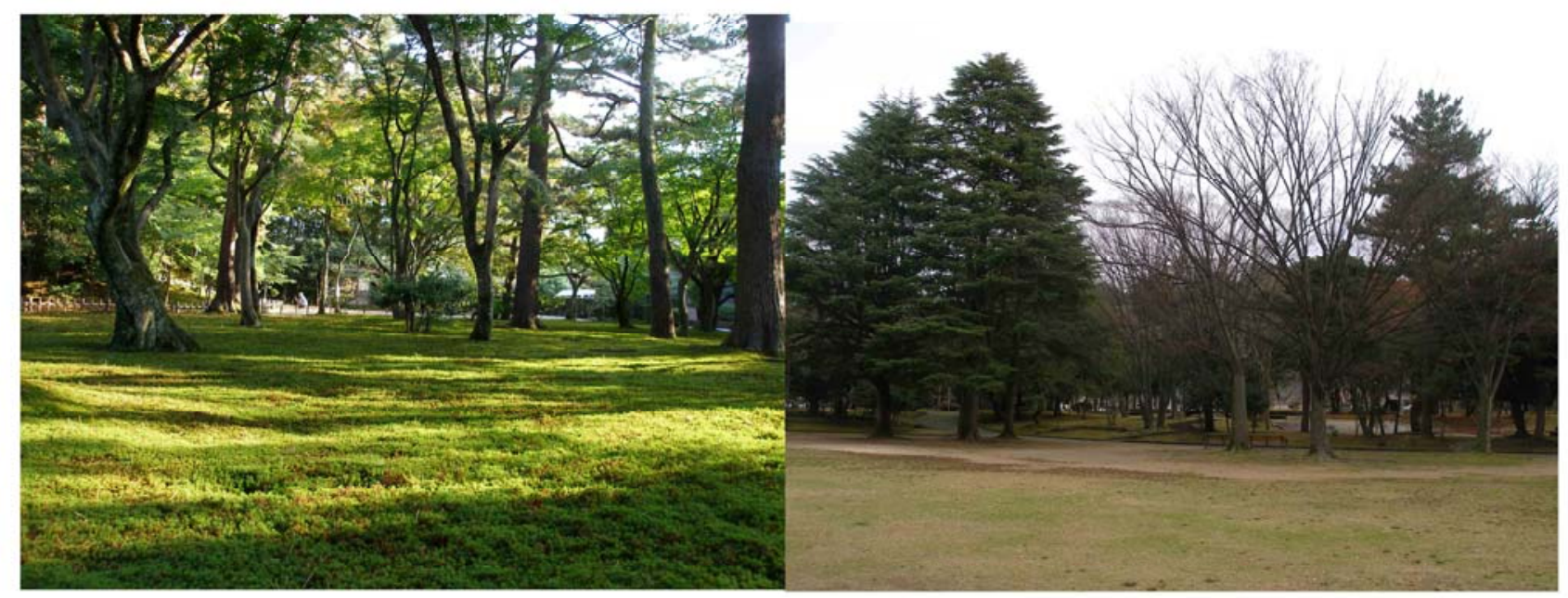

A. Japanese garden

B. Urban park

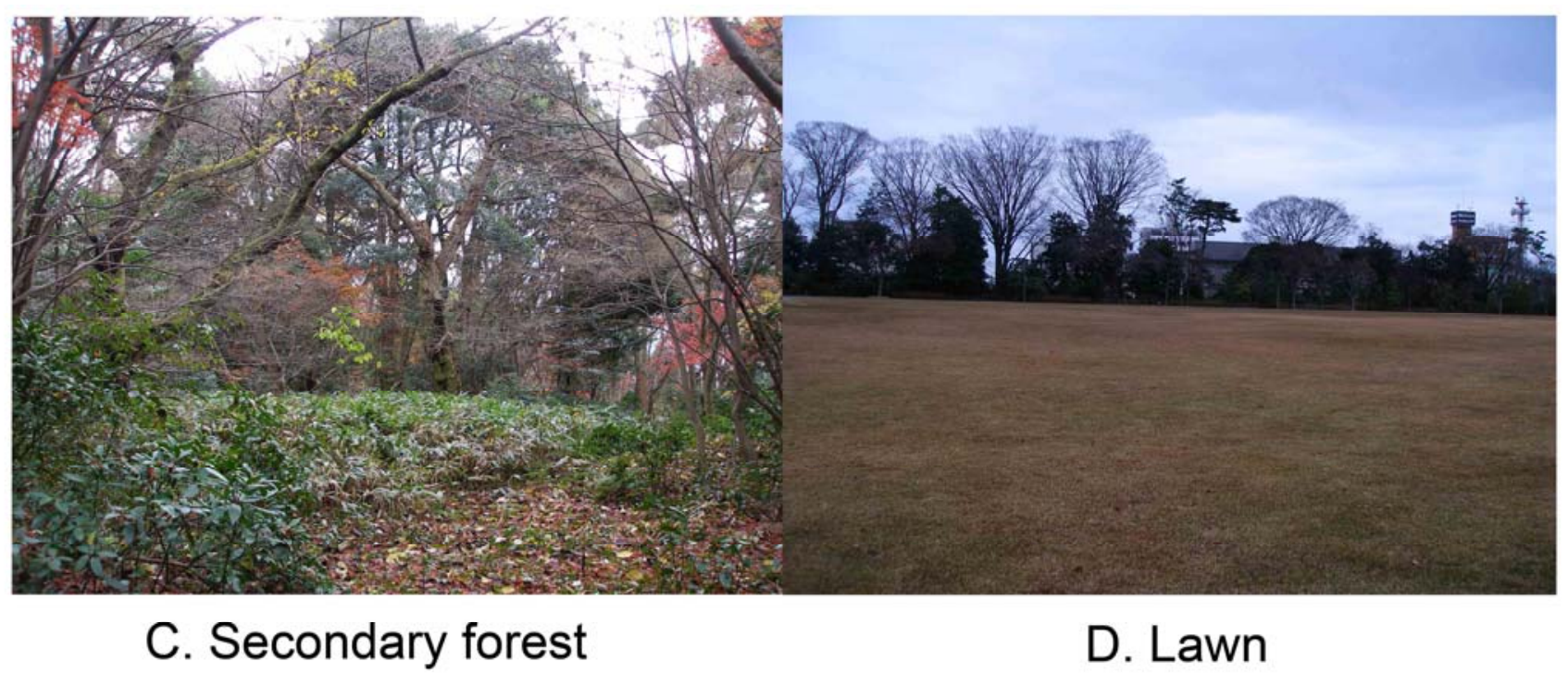

Fig. 3 

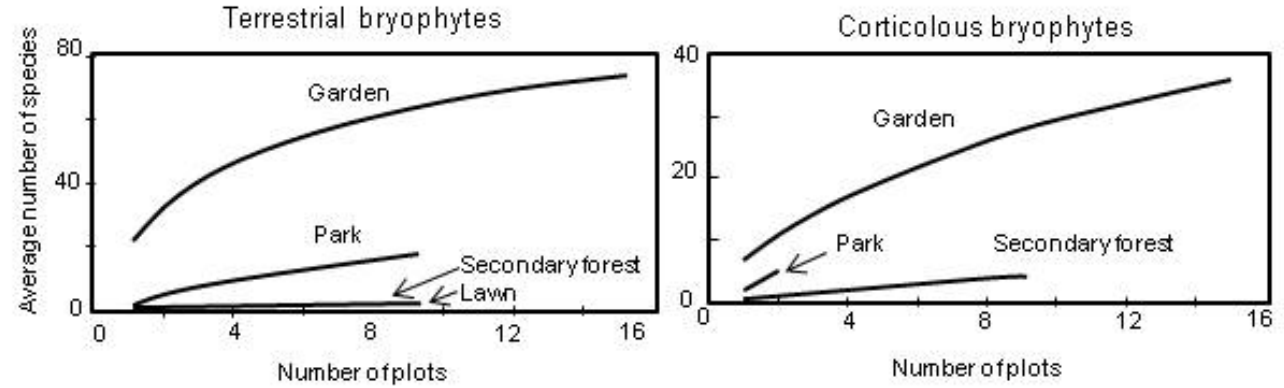

Fig. 4 


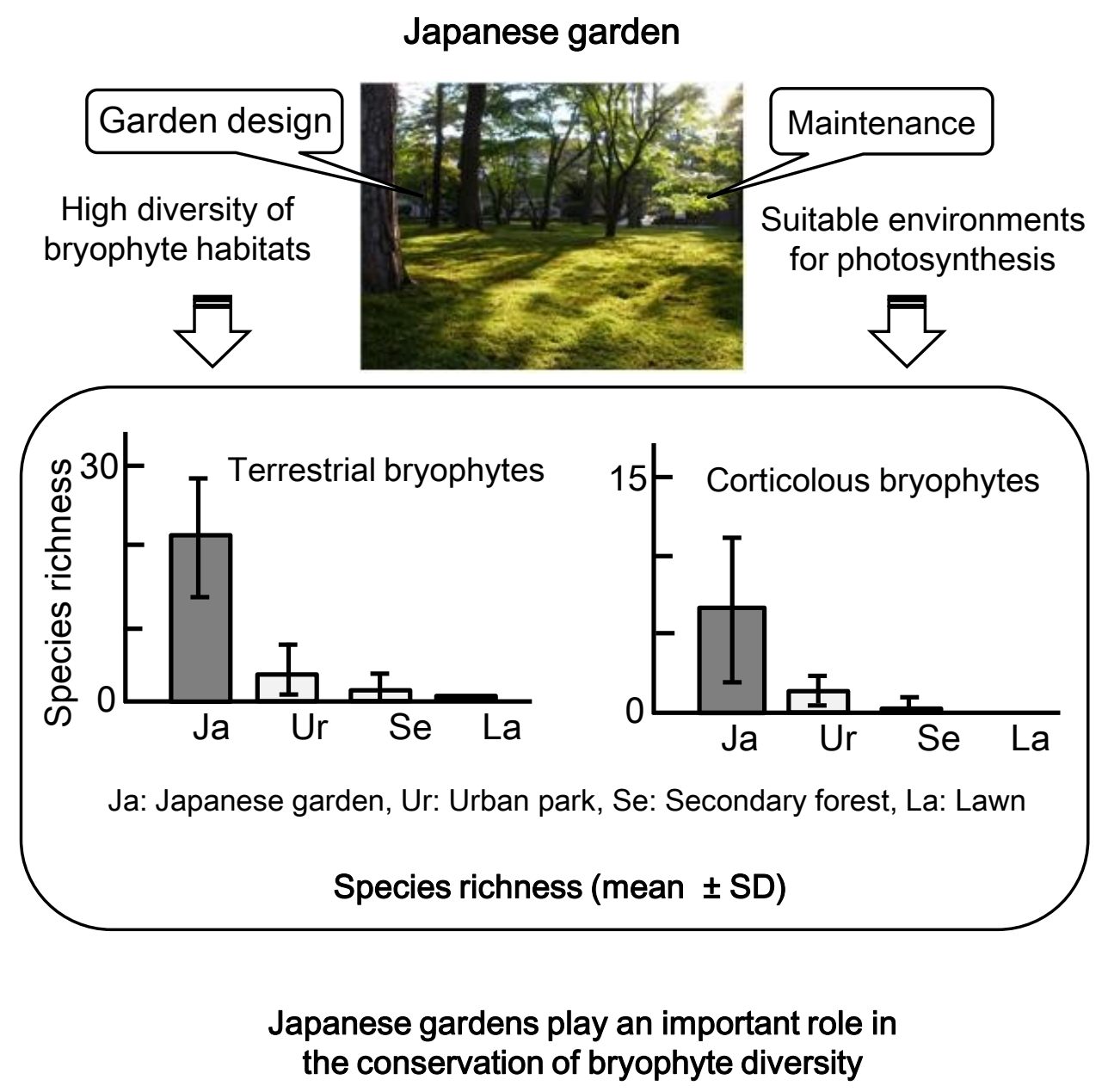

Graphic abstract 